\title{
ICE FORMATION AND ICE STRUCTURE ON LAW DOME, ANTARCTICA
}

\author{
by
}

\section{XIE ZicHU}

Lanzhou Institute of Glaciology and Cryopedology, Academia Sinica, Lanzhou, Gansu, People's Republic of China

ABSTRACT

Snow stratigraphical studies, together with crystallographic and oxygen isotope analyses, have affirmed the existence of a complete range of ice formation zones on the Law Dome, Antarctica. Asymmetric distribution of these zones and changes in the types of ice formation with depth in snow pits dug near the boundaries of the zones show an asymmetry in accumulation and thermal conditions in different sites on Law Dome, and a climatic change in past years. Crystallographic studies of ice from two boreholes near Cape Forger (BHC 1 and BHC 2) show change of microtexture and fabric of the ice crystals with depth. Six different layers of ice can be identified: 1) a deposition layer with polygonal shaped crystals, an ice fabric which is dependent on the ice formation process; 2) a transition layer with porphyrblastic crystals and a girdle fabric pattern developing toward a two-pole fabric; 3) a fine grained layer with cataclastic crystals and strong, nearly vertical single pole c-axis fabric; 4) a coarse grained layer with large, interlocking, branched crystals and a diamond pattern of fabric; 5) a second fine grained layer with single maximum fabric; 6) a second coarse grained layer with multi-maxima fabric. The origin of the second fine grained layer, found in the ice of the last glaciation is discussed. The author suggests that this ice results from conditions during the last glaciation.

\section{INTRODUCTION}

Law Dome, a local ice cap about $200 \mathrm{~km}$ in diameter with summit height of $1395 \mathrm{~m}$ a.s.1., is situated on the edge of the main East Antarctic ice sheet near the Australian Antarctic Station Casey. The snow stratigraphic studies on Law Dome started in the late 1950s and the investigation of the ice structure in the 1970 s by American and Australian glaciologists. Main results of their studies are published in the papers of Cameron and others 1959; Hollin and Cameron 1961; Hollin and others 1961; Cameron and Bull 1962; Budd 1966; Budd 1972; Matsuda and others 1976; and Russell Head and Budd 1979.

As part of the cooperative programme of scientific studies in Antarctica under an agreement between Australia and China, the author was invited to participate in the 1982 Australian National Antarctic Research Expedition (ANARE) to Casey Station and had the opportunity to make a study of snow stratigraphy and ice structure on Law Dome.

\section{ICE FORMATION ON LAW DOME}

Determination of the characteristics of the ice formation and its distribution on Law Dome was the main aim of the author in his study of snow stratigraphy, in order to investigate the accumulation-ablation processes of snow on the surface of the polar ice sheet. Ordinary snow stratigraphic and crystallographic as well as oxygen isotope methods were used in more than 20 snow pits along the traverse routes at particular sites (Figure 1). The results of these studies affirmed the existence of a complete range of ice formation zones on Law Dome following the terminology of Shymskii $(1955,1962)$.

As shown in Figure 2, between the coast and the summit of Law Dome, the following progression was observed: ablation zone, infiltration-congelation (superimposed ice) zone, infiltration (wet snow) zone, cold infiltration (percolation) zone, regelation-recrystallization zone

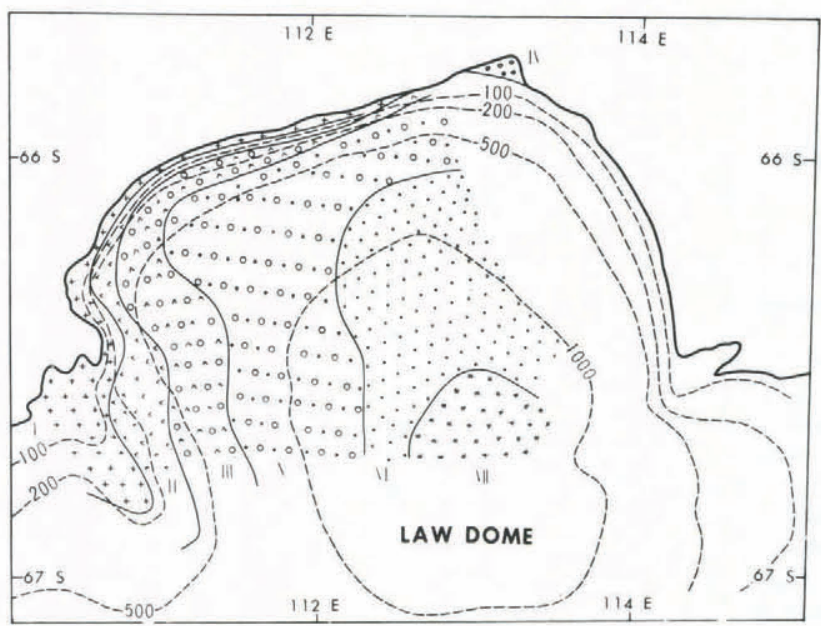

Fig.1. Map of Law Dome with surface elevation contours, showing location of traverse routes, pit and sampling sites, and of borehole sites and other key points.

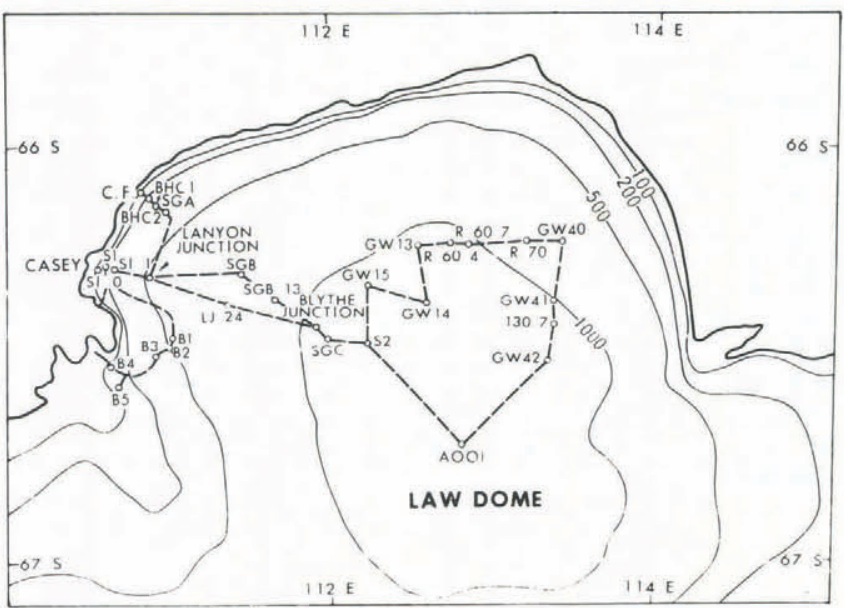

Fig.2. Map showing the geographical distributions of ice formation zones on Law Dome. I Ablation zone; II Infiltration-congelation zone; III Infiltration zone; IV Warm infiltration zone; V Cold infiltration zone; VI Regelation-recrystallization zone; VII Recrystallization zone.

and recrystallization (dry snow) zone. It was hyphothesized that a warm infiltration-recrystallization zone existed on the northeast coast resulting from the high rate both of accumulation and ablation near the coast.

The distribution of these zones on Law Dome was asymmetric: zonal boundaries occurred at higher elevation on the west side than on the east (Figure 2), reflecting the asymmetry in accumulation and thermal conditions. 


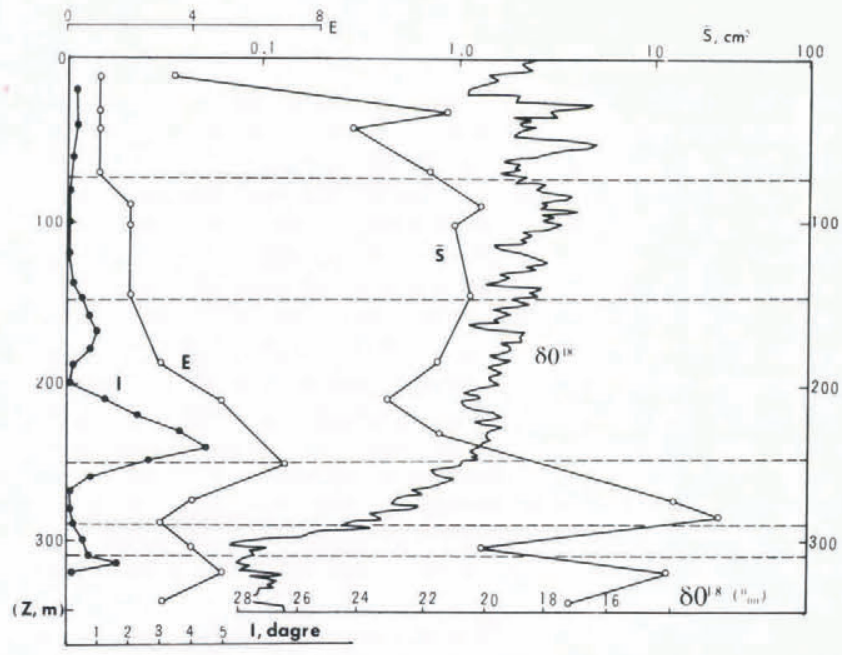

Fig.3. Curves showing change of crystal size $(\overline{\mathrm{S}})$, bubble elongation ratio $(\mathrm{E})$, borehole inclination for 1 year (I), and oxygen isotope ratio $\left(\mathrm{sO}^{18}\right)$ with depth $(\mathrm{Z})$ for $\mathrm{BHC}$ 2 .
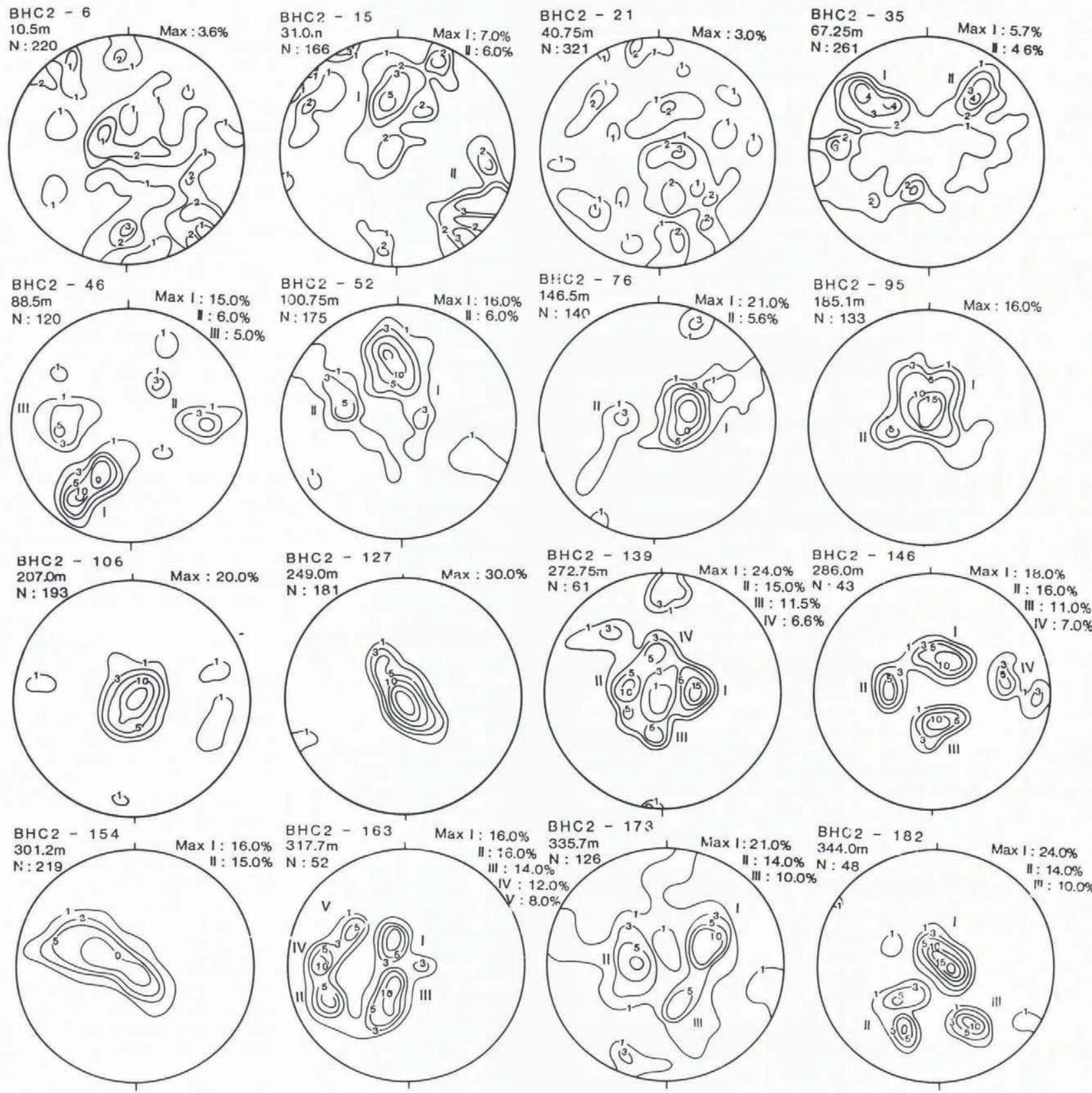

$3 \mathrm{HC} 2-173$

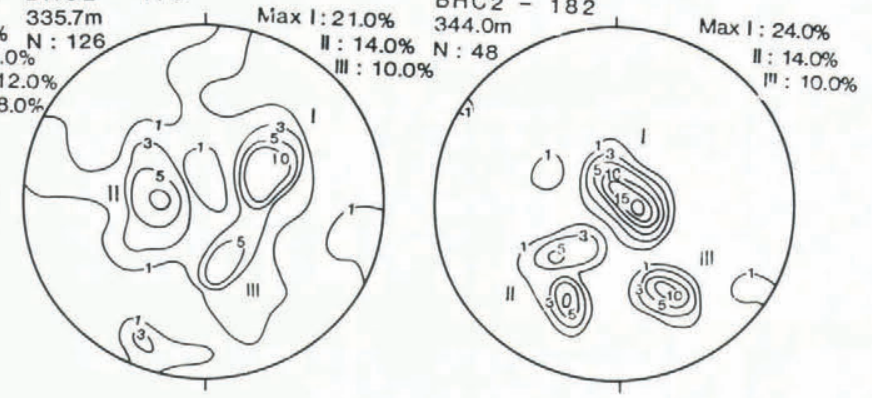

Fig.4. Fabric diagram of thin sections of ice cores from BHC2 $(1-3-5-10-15-20-25 \%$ per $1 \%$ area). 
for every sample included texture and air bubble observations, ice crystal size and ice fabric measurements. Because of the similarity of the results of crystallographic borehole and ice core studies for $\mathrm{BHC} 2$ and $\mathrm{BHCl}$, only the results of $\mathrm{BHC} 2$ are shown in Figures 3 and 4 .

The ice crystallographic characteristics of BHC 1 and BHC 2 were quite similar. The change of microtexture, crystal size and fabric of ice crystals with depth could be identified in the following six different layers:

\section{1) A slightly metamorphosed deposition layer.}

This layer developed from the firn-ice transition boundary at depths of $10.5 \mathrm{~m}$ in BHC 2 and $15 \mathrm{~m}$ in BHC 1 , to $70 \mathrm{~m}$ in $\mathrm{BHC} 2$ and $50 \mathrm{~m}$ in BHC 1 respectively. Microstructure showed increasing complication with depth, but the polygonal shape of crystals remained unchanged. Crystal size was increasing with depth, a result of a recrystallization process. Ice fabrics developed from random configuration to an indistinctly incomplete girdle appearance. In comparison with bubbly ice, the transparent ice found at $31 \mathrm{~m}$ for BHC 2 and at $25-40 \mathrm{~m}$ for BHC 1 had an early developed and preferential fabric, with an indistinct two-maxima pattern and bigger crystals. It could be explained that the transparent ice had a congelation origin which formed earlier than that of bubble infiltration ice and underwent a longer metamorphosis. Comparison with the oxygen isotope curve prepared by V. Moregn showed that the transparent ice formed in a warmer period.

\section{2) A transition layer with porphyrblastic crystals}

Crystal size changed a little, reflecting an increasing shear strain limiting the growth of crystals. Ice fabric pattern showed a girdle transforming into a two-pole fabric. The depths of these layers were $150 \mathrm{~m}$ in BHC 2 and 135 $\mathrm{m}$ in BHC 1 respectively.

3) A fine-grained layer with cataclastic crystals and strong, nearly vertical single pole $c$-axis fabric.

Air bubbles in ice were elongated in the direction of ice flow. Thus this layer corresponded to the layer of high shear and was proved by measurements of borehole inclination. The depth of this layer reached $250 \mathrm{~m}$ in BHC 2 and $223 \mathrm{~m}$ in $\mathrm{BHC} 1$.

4) A coarse-grained layer with large, interlocking branched crystals and multi-maxima (diamond pattern) c-axis fabric.

The elongation ratio of air bubbles decreased. This layer developed to $290 \mathrm{~m}$ in BHC 2 and 255 in BHC 1 .

5) A second fine-grained layer with cataclastic but interlocking crystals.

The elongation of air bubbles increased. A single maximum fabric extending in the direction of ice flow appeared again. These layers, corresponding to the second high shear ice layer, thickened to $310 \mathrm{~m}$ in BHC 2 and 261 $\mathrm{m}$ in $\mathrm{BHC} 1$ respectively. These layers dated back to the period of the last glaciation, as shown by oxygen isotope curves.

6) A second coarse-grained layer with large interlocking branched crystals and a multi-maxima fabric, with centre of symmetry inclining away from the vertical.

The elongation of air bubbles decreased again, the layers reaching to the bottom of both boreholes. Borehole inclination and oxygen isotope data both showed that the two layers of single maximum fabric corresponded to the two layers of high shear and that the second layer contained ice dating back to the period of the last glaciation.

Two layers with single maximum c-axis fabric were also found in the SGA borehole about $300 \mathrm{~m}$ upstream from BHC 1 (Matsuda and others 1976) and in the SGF borehole $4 \mathrm{~km}$ further upstream found by the author. The second layer with single maimum c-axis fabric also contained ice dating back to the period of the last glaciation.

\section{SPECIAL CRYSTALLOGRAPHIC FEATURES OF ICE} FROM THE LAST GLACIAL MAXIMUM

Ice originating from the last glacial maximum obtained from many different sites, has common crystallographic features. These become clear in particular when one compares the crystal properties of ice from the Holocene with those of ice from the Wisconsin period.

A marked decrease in crystal size at the boundary between the Holocene and Wisconsin ice has also been reported for Camp Century, Greenland (Herron and Langway 1980), Devon Island ice cap, Canada (Koerner and Fisher 1979) and for the following Antarctic sites: Byrd Station (Gow and Williamson 1976), Vostok (Korotkevith and others 1978), Dome C (Duval and Lorius 1980). Where orientation fabrics have been measured, the finer grained ice of the Wisconsin period is found to have a single-pole fabric. This evidence suggests that climate may modify or otherwise influence the crystallographic processes involved with grain growth and fabric development, as noted by Koerner and Fisher (1979), Herron and Langway (1982) and Paterson (1981)

Possible factors affecting the crystallographic properties of ice may result from large variations of trace chemical content and microparticle concentration. At all sites studied, ice from the late Wisconsin period typically contains several-fold higher concentrations of chemicals and microparticles than ice from the Holocene or earlier periods. This increase in impurities has been explained by increased vigour of the atmospheric circulation, increased atmospheric activity and the presence of large areas of exposed continental shelf. The concentrations were further enhanced by lower precipitation levels during the cold glacial maximum. Difference in the crystal size could also be due to different crystal growth at different temperature, according to Duval and Lorius (1980).

These conditions are comparable to those found in the East Tian Shan and the Qilian Shan, where glaciers are of continental type with monsoonal nourishment (Xie 1980). There winters are arid and summers moist. A strong dust layer is found on the glaciers corresponding to the winter period, when accumulation is small, winds are stronger and there is increased dust transport from surrounding deserts.

It is not known which of the components of the impurities contained in the Wisconsin ice could affect crystallographic properties, or whether some other process occurred at the time of the formation of the snow. More work, both in the field and in the laboratory, is required to explain these differences and resolve the questions posed here.

\section{ACKNOWLEDGEMENTS}

I thank N Young and I Allison, Glaciology Section of Antarctic Division, Department of Science and Technology, Australia, for many valuable discussions and guidance in this work; Professor W F Budd, Meteorology Department, University of Melbourne for his timely and useful advice, and $\mathrm{T}$ McCray, D Etheridge, V Morgan and $\mathrm{E}$ Wishart of the Glaciology Section for their friendly cooperation in the field and in Melbourne.

\section{REFERENCES}

Budd W F 1966 Glaciological studies in the region of Wilkes: Eastern Antarctica, 1961. ANARE Scientific Reports Series (IV) Glaciology Publication no. 88

Budd W F 1972 The development of crystal orientation fabrics in moving ice. Zeitschrift für Gletscherkunde und Glazialgeologie VIII(1-2): 65-105

Cameron R L, Loekn O H, Molhohm J R T 1959 Wilkes Station Glaciological data 1957-58. Ohio State University Research Foundation, Project 825. Report 1(3)

Cameron R L, Bull C B 1962 The thermal diffusivity and conductivity of glacial ice at Wilkes Station, Antarctica. American Geophysical Union, Antarctica Research Reports.

Duval P, Lorius C 1980 Crystal size and climatic record down to the last ice age from Antarctic ice. Earth Planetary Science Letters 48: 59-64

Gow A I, Williamson T 1976 Rheological implications of the internal structure and crystal fabrics of the West Antarctic ice sheet as revealed by deep core drilling at Byrd Station. Geological Society of America Bulletin 87: 1665-1677

Herron S L, Langway G C 1982 A comparison of ice fabrics and textures at Camp Century, Greenland and Byrd Station, Antarctica. Annals of Glaciology 3: 118-124 
Hollin J T, Cameron R L 1961 IGY glaciological work at Wilkes Station, Antarctica. Journal of Glaciology 3: 833-844

Hollin J T, Cronk C, Robertson R 1961 Wilkes Station Glaciology, 1958. Ohio State University, Research Foundation Report 825-2

Koerner R M, Fisher D A 1979 Discontinuous flow, ice texture and dirt content in the basal layer of the Devon Island ice cap. Journal of Glaciology 23: 209-221

Korotkevich Ye S, Petrov V N, Barkov N I, Sukhonosova L I, Dmitriyev D N, Portnov V G 1978 [Results of studies of the vertical structure of the Antarctic ice sheet near Vostok Station.] Informationary Byulleten Sovetskoy Antarkticheskoy Expeditsii 97: 135-148 (in Russian)

Matsuda M, Wakahama, G, Budd W F 1976 Twinning of ice from Antarctic ice sheet. Low Temperature Science Ser.4 (34): 163-171

Paterson W S B 1981 The physics of glaciers. 2nd edition. Pergamon Press

Russell-Head D S, Budd W F 1979 Ice sheet flow properties from combined borehole shear and ice core studies. Journal of Glaciology 24: 117-130

Shumskii P A 1955 Principles of structural glaciology. (in Russian) Translated into English in 1964

Shumskii P A, Chikin E N 1962 [On problems of glaciological zonation.] Materials of Glaciological Studies Chronicle. Discussion no 5 (in Russian)

Xie Zichu 1980 [Mass balance of glaciers and its relationship with characteristics of glaciers.] Journal of Glaciology and Cryopedology 2(4): 1-10 (in Chinese with English abstract) 